\title{
Zika in Singapore: insights from One Health and social medicine
}

\author{
Tamra Lysaght ${ }^{1}$, PhD, Tsung-Ling $\underline{\text { Lee }}^{1}$, SJD, Sangeetha Watson $^{1}$, MA, Zohar Lederman ${ }^{1}$, MD, Michele Bailey ${ }^{2}$, DvM, \\ Paul Anantharajah $\underline{\text { Tambyah }}^{3}$, MD
}

$\mathrm{T}$ he detection of the Zika virus in Singapore in the last week of August 2016 has generated concern in the community, particularly among pregnant women, and prompted the authorities to take swift action to contain the spread of the virus. In addition to public health efforts currently under way, including the lively ethical discourse on dealing with this mild disease and its significant risk of congenital malformations, we believe that important insights can also be found in the One Health $(\mathrm{OH})$ approach. $\mathrm{OH}$ is an ethical, ecological approach that takes into consideration justice and respect for human and animal populations as well as the environment. ${ }^{(1-3)}$ This approach considers the wider social and environmental factors that shape disease transmission, and helps us to identify three populations that are particularly vulnerable but may be overlooked in this scenario: transient foreign workers, their sexual partners and local monkey populations.

A disproportionate number of transient foreign workers in Singapore have been infected with the Zika virus; of the initial 56 confirmed cases of Zika, 38 were foreign workers working at a construction site at Sims Drive. The $\mathrm{OH}$ approach is valuable, as it takes into consideration the social and environmental factors that have exposed foreign workers to a greater risk of contracting the Zika virus. These transient workers are vulnerable due to their limited choices of living arrangements and working conditions - factors that they have almost no control over. Providing these workers with safe and clean working environments is essential to the immediate response and long-term management of Zika. There is a lack of evidence to support the effectiveness of vector control methods such as fogging, ${ }^{(4)}$ as the Aedes mosquito may be found in inaccessible places many storeys above the ground $^{(5)}$ and can develop resistance to insecticides. ${ }^{(6)}$ The $\mathrm{OH}$ approach encourages sound interventions that carry little risk to humans, animals and the environment, focusing instead on the ecological conditions that promote the Aedes breeding cycle. A wider review of environmental management practices in the construction industry may be warranted to prevent further outbreaks.

The Zika virus is also transmitted through sexual contact, which leads us to the second vulnerable group - female sexual partners of transient workers. This group is likely to include lowwage foreign workers who are particularly vulnerable due to their lack of education, limited English fluency and often insecure employment situation. These workers are currently not eligible for the government subsidy for Zika screening, and thus, the need to pay the full cost of the test may act as a deterrent to getting tested. (7) If they are casual workers, the issues may be compounded by the limited access to screening provided for licensed workers, who may travel without the disease being detected. ${ }^{(8)}$ To minimise the spread of the disease within Singapore and around the region, ${ }^{(9)}$ it is critical that appropriate information reaches these women and that they have access to subsidised testing and resources for safe sex.

The third potentially vulnerable population is the local cynomolgus monkeys. Zika is a zoonotic disease that is now being efficiently transmitted between humans; however, it was first isolated from rhesus monkeys in Uganda in 1947.(10) Although there is no evidence that non-human primates are involved in the spread of the Zika virus, ${ }^{(11)}$ it may be speculated that due to the close relation between the cynomolgus and rhesus monkeys, the virus could also possibly infect cynomolgus monkeys via mosquitoes. ${ }^{(12)}$ However, to date, there are no studies that support this claim. Public health authorities often resort to culling as a measure to control disease outbreak, although such interventions are frequently ineffective, morally objectionable and lack public support. The $\mathrm{OH}$ approach encourages the allocation of resources to investigate the prevalence of the Zika virus in non-human primates, and to develop and implement interventions that benefit humans, animals and the environment. For example, it would be more appropriate and ethically sound to accelerate the development of vaccines for those who may be susceptible to the virus - both human and non-human animals.

In conclusion, the $\mathrm{OH}$ approach can provide important lessons for dealing with the current outbreak and other emerging infectious diseases. As an ethical, ecological approach, $\mathrm{OH}$ emphasises that working in silos to control an outbreak is not only unjust, but also likely to be ineffective. An effective $\mathrm{OH}$ response requires a collaborative, cross-disciplinary approach that considers the ecology of Singapore to be a space jointly shared by humans (both foreign and local) and non-human animals, as well as the environment we all live in. This response requires the cooperation of experts in public health, clinical medicine, environmental management, veterinary science, ecology, virology, sociology and other related disciplines. Furthermore, as Zika is also present in neighbouring countries, the response should extend beyond the borders of Singapore to help control the spread of the disease in the region. This is the only way to ensure optimal health for humans, animals, and the environment in Singapore and beyond. 


\section{ACKNOWLEDGEMENTS}

This research was supported by funding from the Communicable Diseases-Public Health Research Grant from the Ministry of Health, Singapore, (MOH/CDPHRG/0011/2014) for the project One Health, Zoonotic Diseases and Pandemic Planning: Creating a Bioethics Framework in Singapore. We acknowledge the support of the project team in developing the framework applied in this paper.

\section{REFERENCES}

1. Capps B, Bailey MM, Bickford D, et al. Introducing One Health to the ethical debate about zoonotic diseases in Southeast Asia. Bioethics 2015; 29:588-96

2. Degeling C, Johnson J, Kerridge I, et al. Implementing a One Health approach to emerging infectious disease: reflections on the socio-political, ethical and legal dimensions. BMC Public Health 2015; 15:1307.

3. Coker R, Rushton J, Mounier-Jack S, et al. Towards a conceptual framework to support one-health research for policy on emerging zoonoses. Lancet Infect Dis 2011; 11:326-31.

4. Bowman LR, Donegan S, McCall PJ. Is Dengue vector control deficien in effectiveness or evidence?: systematic review and meta-analysis. PLoS Negl Trop Dis 2016; 10:e0004551.
5. Liew C, Curtis CF. Horizontal and vertical dispersal of dengue vector mosquitoes, Aedes aegypti and Aedes albopictus, in Singapore. Med Vet Entomol 2004; 18:351-60.

6. Koou SY, Chong CS, Vythilingam I, Lee CY, Ng LC. Insecticide resistance and its underlying mechanisms in field populations of Aedes aegypti adults (Diptera: Culicidae) in Singapore. Parasit Vectors 2014; 7:471.

7. Koh F. Offer subsidised tests to foreign workers too, says advocacy group. In: The Straits Times [online]. Available at: http://www.straitstimes.com/ singapore/offer-subsidised-tests-to-foreign-workers-too-says-advocacygroup. Accessed September 13, 2016.

8. Wong ML, Chan $\mathrm{R}$, Tan $\mathrm{HH}$, et al. Sex work and risky sexual behaviors among foreign entertainment workers in urban Singapore: findings from Mystery Client Survey. J Urban Health 2012; 89:1031-44.

9. Wong ML, Chan RK, Koh D, et al. A comparative study of condom use and self-reported sexually transmitted infections between foreign Asian and local clients of sex workers in Singapore. Sex Transm Dis 2005; 32:439-45.

10. Mo Y, Alferez Salada BM, Tambyah PA. Zika virus-a review for clinicians. Br Med Bull 2016; 119:25-36.

11. Zika and Animals. In: Centers for Disease Control and Prevention [online]. Available at: http://www.cdc.gov/zika/transmission/qa-animals.html. Accessed September 1, 2016.

12. Leung GH, Baird RW, Druce J, Anstey NM. Zika virus infection in Australia following a monkey bite in Indonesia. Southeast Asian J Trop Med Public Health 2015; 46:460-4. 